\title{
Western ragweed effects on herbaceous standing crop in Great Plains grasslands
}

\author{
LANCE T. VERMEIRE AND ROBERT L. GILLEN
}

Authors are research assistant, Department of Range, Wildlife, and Fisheries Management, Texas Tech University, Lubbock, Tex. 79409; and rangeland sci entist, USDA-ARS, 2000 18th Street, Woodward, Okla. 73801. At the time of the research, authors were research assistant and professor, Department of Plant and Soil Sciences, Oklahoma State University, Stillwater, Okla. 74078.

\begin{abstract}
Western ragweed [Ambrosia psilostachya DC. ], a major forb species in mixed and tallgrass prairies, is considered to have little value for cattle grazing but is an important food item for bobwhite quail [Colinus virgini anus ]. While often thought to be a strong increaser with grazing pressure, information on the actual relationship between western ragweed and grasses is contradictory. Our objectives were to 1 ) determine the effect of western ragweed on grass standing crop, and 2) determine the effect of vegetation type and grazing on survival and shoot morphology of western ragweed. Western ragweed did not appear to reduce grass standing crop. Instead, standing crop (40 to $620 \mathrm{~kg} \mathrm{ha}^{-1}$ ) and density (6 to 41 shoots $\mathrm{m}^{-2}$ ) of western ragweed were positively related to grass and grassforb standing crop in mixed prairie. Standing crop of western ragweed was not related to grass standing crop in tallgrass prairie. Competitive thresholds for western ragweed in mixed and tallgrass prairies appear to be above the levels observed in this study. Density of western ragweed shoots decreased over the growing season under both grazed and ungrazed treatments. Survival of western ragweed shoots from June to September was greater in mixed prairie $(\mathbf{8 1} \%)$ than in tallgrass prairie $(63 \%)$ and was greater in ungrazed $(76 \%)$ than grazed plots $(68 \%)$. Western ragweed shoots weighed less per unit of height in tallgrass prairie. Western ragweed shoots in ungrazed plots were taller than shoots in grazed plots but weighed less per unit of height. These differences in shoot morphology are consistent with increased competition for light in tallgrass prairie and in ungrazed sites. Western ragweed may not directly reduce grass standing crop but, rather, increase only when grasses are reduced by other stresses such as improper grazing.
\end{abstract}

Key Words: Ambrosia psilostachya, plant competition, grazing effects

Western ragweed [Ambrosia psilostachya DC.] is often the most abundant forb in Great Plains grasslands. Western ragweed is considered a detriment to livestock production because of competition with forage grasses (Elder 1951). On the other hand, seeds of western ragweed are the most important single food item for bobwhite quail [Colinus virginianus ] in Oklahoma (Baumgartner et al. 1952). The response of western ragweed to grazing is variable. Western ragweed increases with increasing stocking rates in tallgrass prairie (Elder 1951, Sims and Dwyer 1965). In mixed prairie, western ragweed decreases with increasing stocking rates (Launchbaugh 1967, Heitschmidt et al. 1989). Brummer et al. (1994) and Reece et al. (1994) observed greater

Manuscript accepted 19 Aug. 1999.
Resumen

"Western ragweed" (Ambrosia psilostachya D.C.), una de las principales especies herbáceas de los pastizales mixtos y altos, se considera de poco valor para el ganado bovino, pero es un importante componente de la dieta del "Bobwhite quail" (Colinus virginanus). Mientras que a menudo se considera que con presión de apacentamiento esta es un especie incresora, la información acerca de la relación actual entre el "Western ragweed" y los zacates es contradictoria. Nuestros objetivos fueron 1) determinar el efecto del "Western ragweed" en la biomasa en pie de los zacates y 2) determinar el efecto del tipo de vegetación en la sobrevivencia y morfología de las ramas del "Western ragweed". El "Western ragweed" parece no reducir la biomasa en pie de los zacates. En cambio la biomasa en pie $\left(40\right.$ a $\left.620 \mathrm{~kg} \mathrm{ha}^{-1}\right)$ y la densidad (6 a 41 ramas $\mathrm{m}^{-2}$ ) del "Western ragweed" se correlacionaron positivamente con la biomasa en pie de los zacates $y$ la biomasa en pie del conjunto zacates-hierbas de las praderas mixtas. La biomasa en pie del "Western ragweed" no se relaciono con la biomasa en pie de los zacates de las praderas altas. Los umbrales competitivos del "Western ragweed" en las praderas mixtas y altas parece ser mayor de los niveles observados en este estudio. La densidad de ramas de "Western ragweed" disminuyo a través de la estación de crecimiento tanto en los tratamientos con y sin apacentamiento. La sobrevivencia de ramas de "Western ragweed' en el periodo de Junio a Septiembre fue mayor $(81 \%)$ en las praderas mixtas que en las praderas altas $(63 \%)$, y fue mayor en las parcelas sin apacentamiento $(\mathbf{7 6} \%)$ que en las que recibieron apacentamiento $(68 \%)$. En las praderas altas las ramas de "Western ragweed" pesaron menos por unidad de altura. Las plantas de "Western ragweed" de los potreros sin apacentamiento fueron mas altas que las de los potreros con apacentamiento, pero pesaron menos por unidad de altura. Estas diferencias en la morfología de la planta son consistentes con el aumento de competencia por luz en los potreros sin apacentar de las praderas altas. El "Western ragweed" puede no reducir directamente la biomasa en pies de los zacates, mas bien se incrementa cuando los zacates se reducen por otras causas estresantes como el manejo inadecuado del apacentamiento.

western ragweed production when grazing was initiated early in the growing season, but intensive-early stocking significantly reduced western ragweed by mid July (Smith and Owensby 1978, McCollum et al. 1990). The impact of western ragweed on other plants is also variable. Western ragweed reduced grass standing crop in tallgrass prairie (Dwyer 1958). In mixed prairie, a posi- 
tive relationship existed between western ragweed and grass standing crops as long as standing crop of western ragweed did not exceed 1,230 kg ha-1 (Launchbaugh 1967). It is difficult to determine the effect of western ragweed on grass growth from herbicide studies because of the presence of other forbs affected by the treatment (Dahl et al. 1989, Powell et al. 1982, Rice and Stritzke 1989). Given the conflicting information on the ecology of western ragweed, it is difficult to prescribe management recommendations, especially the need for and timing of control measures. The objectives of this study were to determine: 1) the effect of western ragweed on grass production, and 2) some basic growth characteristics of western ragweed in tallgrass and mixed prairies.

\section{Materials and Methods}

\section{Study Area}

The first study area, supporting highseral tallgrass prairie was located in northcentral Oklahoma on the Oklahoma State University Research Range, about $21 \mathrm{~km}$ southwest of Stillwater $\left(36^{\circ} 04^{\prime} \mathrm{N}, 97^{\circ} 13^{\prime} \mathrm{W}\right.$, elev. $280 \mathrm{~m}$ ). The climate is continental with average annual precipitation of 831 $\mathrm{mm}, 65 \%$ of which falls as rain from May to October (Myers 1982). The 204-day frost-free growing period occurs from April to October. In January, daily minimum and maximum temperatures average $-4^{\circ} \mathrm{C}$ and $9^{\circ} \mathrm{C}$. Daily minimum and maximum temperatures in July average $21^{\circ} \mathrm{C}$ and $34^{\circ} \mathrm{C}$. The study was conducted on shallow prairie ecological sites with slopes of 2 to $3 \%$. The soil was a Grainola clay loam (fine, mixed, thermic Vertic Haplustalf), with a clay loam surface, a clay subsoil, and a solum depth of 50 to $80 \mathrm{~cm}$. Dominant plant species included big bluestem [ Andropogon gerardii Vitman], little bluestem [Schizachyrium scoparium (Michx. ) Nash], indiangrass [ Sorghastrum nutans (L.) Nash], and tall dropseed [Sporobolus asper (Michx) Kunth]. The second study area, supporting high seral mixed prairie, was in southwest Oklahoma on the Marvin Klemme Range Research Station near Clinton $\left(35^{\circ} 22^{\prime} \mathrm{N}, 99^{\circ} 04^{\prime} \mathrm{W}\right.$, elev. $490 \mathrm{~m}$ ). The climate at this site is also continental. The average annual precipitation is $766 \mathrm{~mm}$ with 69 percent falling as rain from April to September. The frostfree growing period is 205 days from April to October. Daily minimum and maximum temperatures in January average $-4^{\circ} \mathrm{C}$ and $10^{\circ} \mathrm{C}$. In July, daily minimum and maximum temperatures average $21^{\circ} \mathrm{C}$ and $36^{\circ}$
C. The study was conducted on red shale ecological sites with slopes of 2 to $3 \%$. The soil was a Cordell silty clay loam (loamy, mixed, thermic Lithic Ustochrept). Cordell soils are shallow with a depth of 25 to $36 \mathrm{~cm}$ over hard siltstone (Moffatt and Conradi 1979). Dominant plant species included sideoats grama [Bouteloua cur tipendula (Michx.) Torr.], buffalograss [Buchloe dactyloides (Nutt.) Engelm. ], and blue grama [Bouteloua gracilis (H. B. K. ) Lag. ex Steud.].

\section{Methods}

Four similar sites were selected for study within each vegetation type. Sites were 0.8 to $8 \mathrm{~km}$ apart and located in different pastures. Pastures were 20 to 49 ha in size. Two plots, each measuring $3 \times 7 \mathrm{~m}$, were established at each site. One plot was open to grazing by yearling cattle from late April to September and one plot was fenced to exclude grazing. Stocking rates were $2.9 \mathrm{AUM} \mathrm{ha}^{-1}$ in the tallgrass prairie pastures and 1.6 AUM ha $\mathrm{Am}^{-1}$ in the mixed prairie pastures. Conservative stocking rates are considered to be $2.2 \mathrm{AUM} \mathrm{ha}^{-1}$ and $0.9 \mathrm{AUM} \mathrm{ha}^{-1}$ for the tallgrass and mixed grass prairies, respectively. Corners of grazed plots were marked with wooden stakes driven to near-ground level. Ungrazed plots were fenced with wire panels and a 1-m strip was maintained between the panels and subplots within the exclosure. Grazed and ungrazed plots were 4 meters apart. Plots were divided into 21 subplots each measuring $1 \mathrm{x} 1 \mathrm{~m}$. Fifteen of these subplots were sampled. Standing herbage levels were visually similar for grazed and ungrazed plots when the study began since plots were randomly selected from within grazed pastures. We removed standing dead herbage in both plots between the first and second years of the study to minimize any possible effects of dead herbage accumulation in the ungrazed plots. In early March of the second year, while vegetation was dormant, all plots were cut to a height of $14 \mathrm{~cm}$ with a rotary mower. The cut herbage was scattered over the plots by the mower and was not removed. Density of western ragweed was determined by counting all emerged shoots in the subplots in early June, midJuly and early September. Standing crops for western ragweed, other forbs, and grasses were determined by separately hand-clipping each component from $0.1 \mathrm{x}$ 1-m quadrats placed within the subplots in September. Quadrats were clipped to ground level. In the second year, height and weight were determined for 1 shoot of western ragweed clipped near the center of each subplot. All herbage was oven-dried 5 days at $48^{\circ} \mathrm{C}$. All variables were averaged over subplots within plots for further analyses. In a separate series of measurements, shoots of western ragweed were collected in each vegetation type to develop growth curves. A transect, open to grazing, was established in a north-south orientation within 50 meters of each pair of plots. The transect was paced at 2-week intervals from mid-May through early October in the second year. At each pace, the height of the shoot of western ragweed located nearest to the toe of the technician was measured. The shoot was then clipped at ground level, oven-dried, and weighed in the laboratory. Twenty shoots were sampled on each transect for a total of 80 shoots in each vegetation type for each sample date. Only ungrazed shoots were collected.

\section{Analysis}

Analysis-of-variance was used to determine the effect of vegetation type and year on standing crops of all vegetation components (SAS Institute 1985). Regression models were than constructed to determine the relationships between standing crops of western ragweed and other vegetation components. Separate regression models were constructed for the independent variables of standing crop and density of western ragweed. Dependent variables were standing crops of grasses, forbs (other than western ragweed), and the combination of grasses and forbs.

Density of western ragweed was analyzed with a repeated measures analysisof-variance. The model contained terms for vegetation type, grazing treatment, year, sample date, and all interactions. Year and sample date were considered repeated variables. A square root transformation was applied to the density data because of heterogeneity of variances. Changes in shoot density were further analyzed by expressing July and September densities as a percentage of the initial density in June. These percentages were then analyzed with a repeated measures analysis-of- variance containing terms for vegetation type, grazing treatment, year, month, and all interactions.

Regression models were constructed to relate western ragweed height, weight, and weight:height ratios to day of year. The models included terms for vegetation type, day of year, and their interactions. Both linear and quadratic terms were included for day of year. Vegetation type was a qualitative variable coded as 0 for mixed prairie and 1 for tallgrass prairie (Neter 
and Wasserman 1974). The full model was fitted and then terms were deleted until all remaining terms were significant $(\mathrm{P}=$ 0.05).

End-of-season western ragweed stem height, weight, and weight:height ratios were analyzed by analysis-of-variance. The model contained terms for vegetation type, grazing treatment, and their interaction. A square root transformation was applied to all of the dependent variables because of heterogeneity of variances.

Where differences occurred in any analysis-of-variance, means were separated by the least significant difference. Unless noted otherwise, an alpha level of 0.05 was used for all hypothesis testing.

\section{Results and Discussion}

\section{Precipitation}

Precipitation was favorable during the May to September growing period at both locations and in both years (Fig. 1). Precipitation during this period was particularly high at the mixed prairie location with $193 \%$ and $169 \%$ of normal received in 1994-95 and 1995-96, respectively. At the tallgrass prairie location, precipitation from May to September was $146 \%$ and $109 \%$ of normal for the 2 study years. Winter-spring drought (November to April) was severe at both study locations in 1995-96. Precipitation in that period was $17 \%$ of average at the mixed prairie location, a record low, and $30 \%$ of average at the tallgrass prairie location.

\section{Standing Crop Relationships}

Standing crop of grasses was lower in mixed prairie than in tallgrass prairie $\left(2,820\right.$ and $\left.5,170 \mathrm{~kg} \mathrm{ha}^{-1}\right)$. Standing crop of western ragweed and other forbs was not affected by vegetation type. Standing crop of grasses and western ragweed was similar across years, but the standing crop of other forbs was greater in 1995 than in 1996 (630 and $250 \mathrm{~kg} \mathrm{ha}^{-1}$ ). Based on these results, data used to develop regression models were pooled over years within vegetation type (except for other forbs).

In mixed prairie, standing crop of western ragweed ranged from 40 to $620 \mathrm{~kg} \mathrm{ha}^{-1}$. These levels of standing crop were positively correlated with grass and grass-forb standing crops (Fig. 2). No relationships existed between the standing crops of grass and other forbs $(\mathrm{P}>0.65)$ or the standing crops of grass and total forbs $(\mathrm{P}>0.12)$. Total forb standing crop ranged from 250 to $1,350 \mathrm{~kg} \mathrm{ha}^{-1}$. Western ragweed densities between 6 and 41 shoots $\mathrm{m}^{-2}$ were also

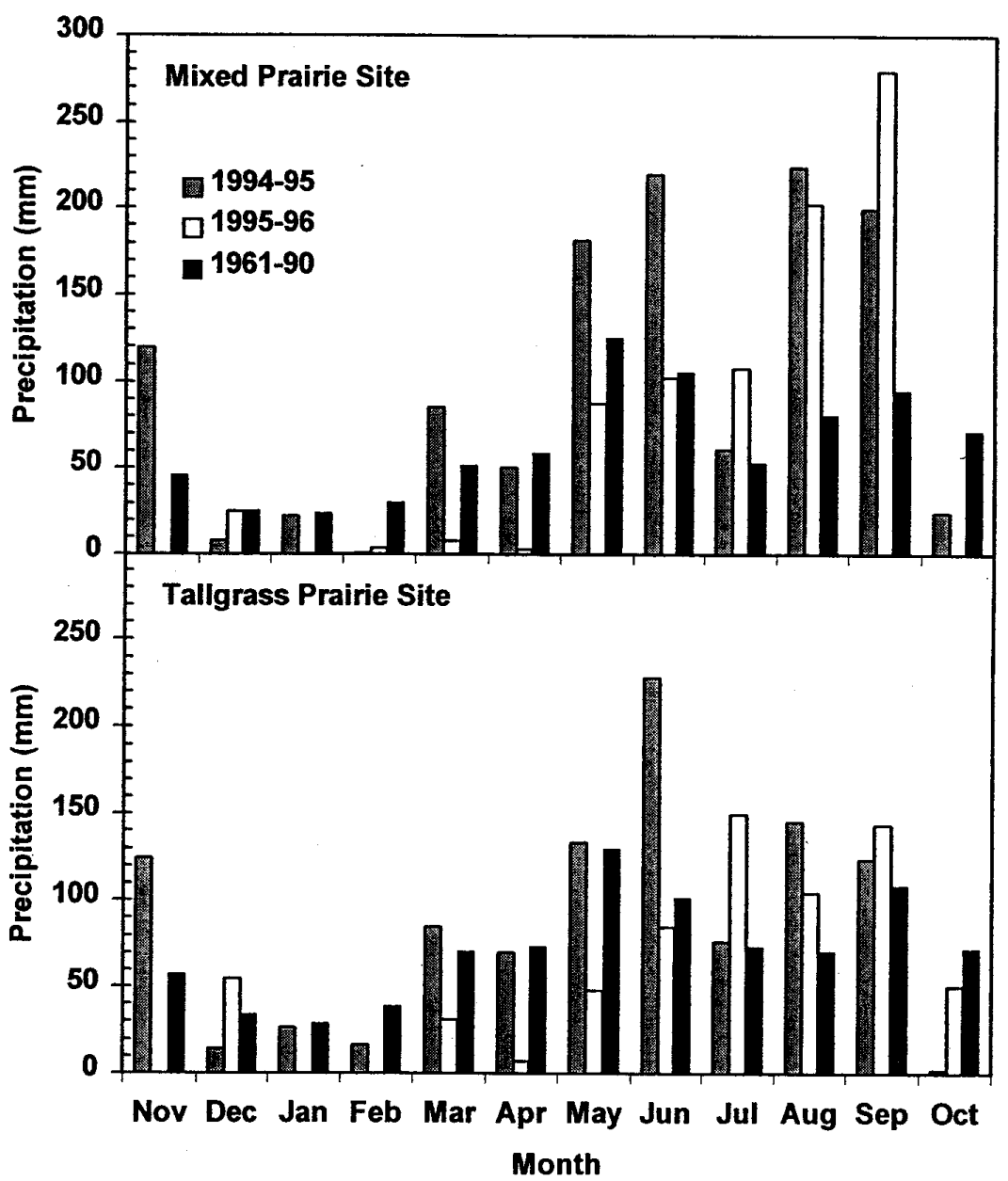

Fig. 1. Study period and long-term mean precipitation received by month at each study location.

positively correlated with grass and grass forb standing crops (Fig. 3).

Launchbaugh (1967) concluded forb

standing crop, almost entirely western ragweed, had to exceed $1,230 \mathrm{~kg} \mathrm{ha}^{-1}$ before grass production was reduced on clay

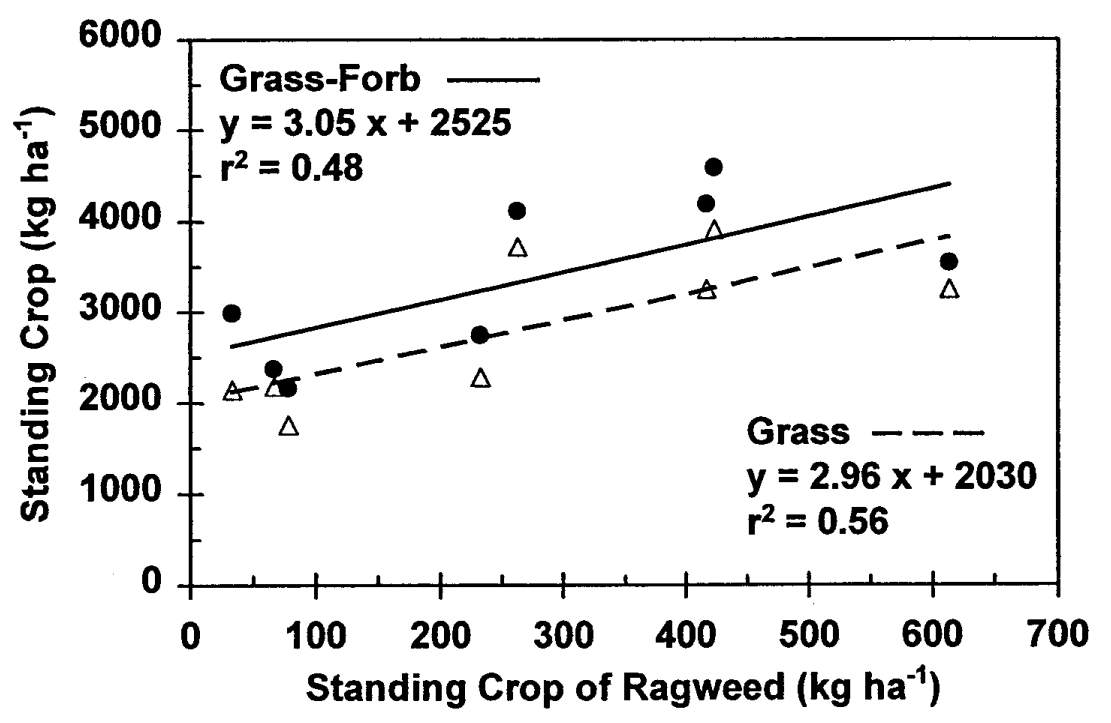

Fig. 2. Relationships of grass (open symbols) and grass-forb (closed symbols) standing crops with western ragweed standing crop in ungrazed mixed prairie. 


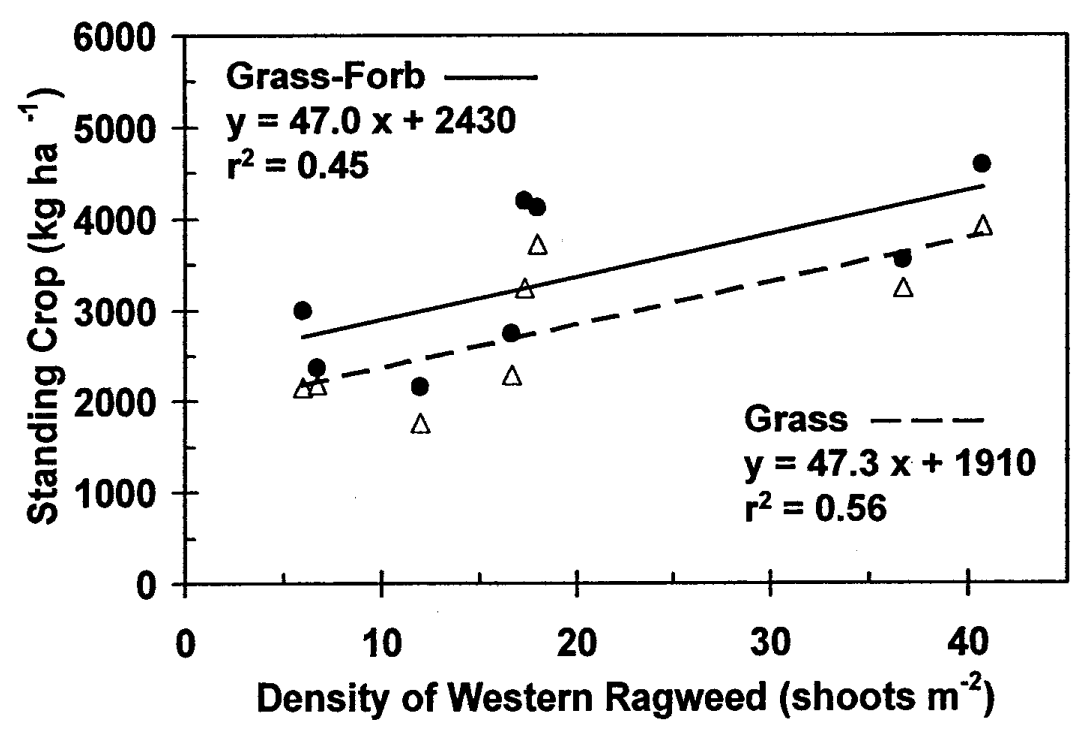

Fig. 3. Relationships of grass (open symbols) and grass-forb (closed symbols) standing crops with western ragweed density in ungrazed mixed prairie.

uplands. On sandy sites, grass standing crop increased up to $1 \mathrm{~kg}$ with control of each kilogram of forbs (Dahl et al. 1989). The forb component was dominated by western ragweed. However, shinnery oak (Quercus havardii Rydb.) was also controlled in the test plots and this may have influenced the release of grasses. Our study and the threshold established by Launchbaugh (1967) indicate relatively large amounts of western ragweed have no effect on the standing crop of grasses in mixed prairie.

One reason for the positive correlation between biomass of western ragweed and grasses was that western ragweed tended to be more abundant on plots dominated by midgrasses, mainly sideoats grama, and less abundant on plots dominated by shortgrasses, mainly buffalograss. Plots dominated by midgrasses also tended to have higher standing crops of grasses. It is likely that water relations were more favorable for plant growth on the midgrass plots. On the same soil, water infiltration and grass production is higher on midgrass-dominated sites compared to shortgrass-dominated sites (Wood and Blackburn 1981, Dormarr et al. 1994). Shortgrass roots form a dense mat in the

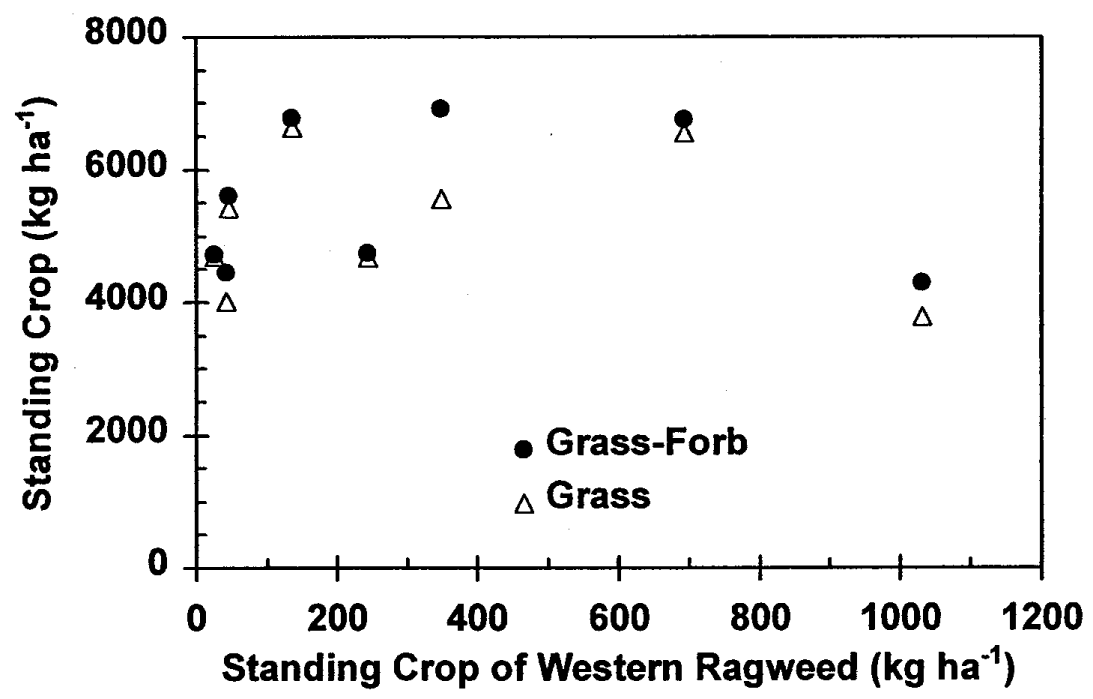

Fig. 4. Relationships between standing crop and density of western ragweed in ungrazed tallgrass (open symbols) and mixed (closed symbols) prairies.

upper soil layers (Weaver 1958). Western ragweed may be more abundant on midgrass areas because of the improved water relations and reduced root competition. Second, forbs may alter the microenvironment to favor increased grass production by providing shade and reducing wind speeds, which in turn reduce evapotranspiration (Launchbaugh 1967, Whitham 1971). Finally, high levels of precipitation during the study may have reduced the impact of soil moisture as a limiting factor for plant growth.

In tallgrass prairie, no relationship existed between the standing crop of grasses and the standing crop of western ragweed when the latter ranged between 30 and $1,030 \mathrm{~kg} \mathrm{ha}^{-1}$ (Fig. 4). The only significant relationship for tallgrass prairie was between density of western ragweed and standing crop of western ragweed (Fig. 5). Simple coefficients of determination of 0.85 and 0.75 indicate densities of western ragweed shoots provided a reasonable estimate of western ragweed standing crop in tallgrass and mixed prairie, respectively. On loamy prairie ecological sites with forb standing crops similar to ours, grass production increased about $1 \mathrm{~kg}$ for every kilogram of forbs controlled by herbicides (Rice and Stritzke 1989, Powell et al. 1982). Grass standing crop increased 0.7 to $0.9 \mathrm{~kg}$ with each kilogram of forbs controlled on claypan sites (Powell et al. 1982). However, these results are confounded by the varying degrees that forbs other than western ragweed were reduced by the herbicide. The presence of other forbs, such as heath aster [Aster ericoides L.], in both of these studies makes it difficult to determine which forb species are most associated with grass response following forb removal.

On another loamy prairie ecological site, above and below-ground standing crop of big bluestem was 56 and $54 \%$ lower, respectively, in the presence of western ragweed at $753 \mathrm{~kg} \mathrm{ha}^{-1}$ and 65 shoots $\mathrm{m}^{-2}$ (Dwyer 1958). This appeared to be the result of direct plant competition because the site had had no grazing or major disturbance for many years. However, this relationship may have been a result of sampling methodology. Quadrats were selectively placed to include only big bluestem or combinations of big bluestem and western ragweed. With selective sampling, it is impossible to determine if the relationship of big bluestem and western ragweed is due to plant competition, inherent soil factors, animal disturbance, or some other unmeasured environmental influence. 


\section{Density of Western Ragweed}

Western ragweed density decreased from early June to early September (Table 1) even with favorable precipitation.

Table 1. Western ragweed density by month averaged over grazing treatment and years.

\begin{tabular}{lccc}
\hline \hline & \multicolumn{3}{c}{ Sample Date } \\
\cline { 2 - 3 } Vegetation type & 1 Jun. & $15 \mathrm{Jul}$. & $1 \mathrm{Sept}$. \\
\hline & $---($ Shoots m & -2 & --- \\
Mixed prairie & $20^{\mathrm{cd} 1}$ & $17^{\mathrm{de}}$ & $15^{\mathrm{e}}$ \\
Tallgrass prairie & $36^{\mathrm{a}}$ & $24^{\mathrm{b}}$ & $21^{\mathrm{bc}}$ \\
\hline
\end{tabular}

${ }^{1}$ Means with different letters are significantly different at $\mathrm{P}<0.05$.

Density of western ragweed was always higher in tallgrass prairie but the difference between vegetation types narrowed as the growing season progressed. Western ragweed density was not affected by year, averaging 24 shoots $\mathrm{m}^{-2}$ in 1995 and 28 shoots $\mathrm{m}^{-2}$ in 1996 . The density of western ragweed averaged 31 shoots $\mathrm{m}^{-2}$ on ungrazed plots and 20 shoots $\mathrm{m}^{-2}$ on grazed plots but this difference was not significant.

Elder (1951) observed a $63 \%$ reduction in density of western ragweed following 3 years of rest. The lack of grazing or year effects or a grazing by year interaction in our study may reflect the above-average precipitation. Initial conditions were also different for the 2 studies. The sites studied by Elder were described as "weedy" at the start of his experiment while our study sites were in a high seral stage. There was probably more potential for change on the "weedy" site. Finally, Elder allowed dead herbage to accumulate over 3 years while we removed standing dead herbage during the dormant season.

Survival of shoots of western ragweed was higher in mixed prairie $(81 \%)$ compared to tallgrass prairie $(63 \%)$. We suggest this is a result of greater light competition in tallgrass prairie. The difference is not likely explained by soil moisture since the tallgrass prairie site received greater precipitation.

Survival to mid July (77\%) was significantly greater than survival to early September (67\%). This indicates that mortality was twice as high during the early portion of the growing season.

Survival of western ragweed tended to be greater in ungrazed plots $(76 \%)$ compared to grazed plots $(68 \%, \mathrm{P}=0.09)$ for both locations. This suggests some shoots were trampled or grazed. We found 5 and $13 \%$ of the shoots had the terminal portions removed by the end of June in mixed

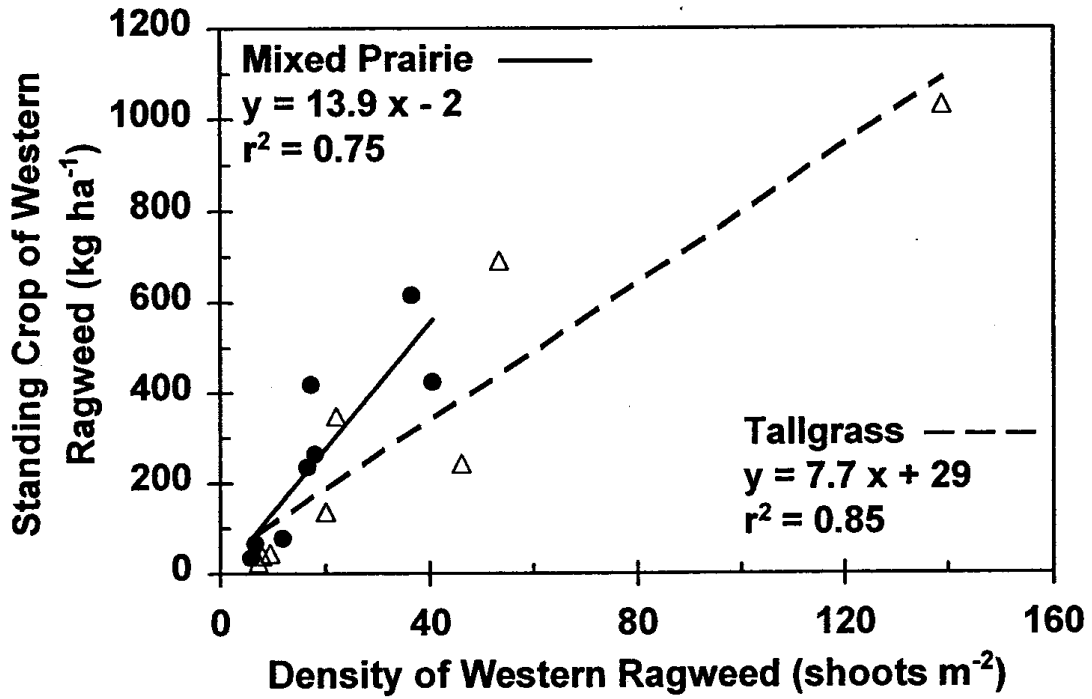

Fig. 5. Relationships between standing crop and density of western ragweed in ungrazed tallgrass (open symbols) and mixed (closed symbols) prairies. and tallgrass prairies, respectively. However, we cannot specifically attribute this grazing to cattle. Cattle graze young western ragweed but it is not a preferred forage plant (Elder 1951). By mid-July, the heavier grazing pressure of intensiveearly stocking reduced forb standing crop, mostly western ragweed, to $54 \%$ of that in pastures stocked season-long in tallgrass prairie (McCollum et al. 1990).

\section{Growth and Morphology}

The rate of height increase for western ragweed was not affected by vegetation type $(p=0.30$, Fig. 6$)$. A simple time expression, day of year, accounted for nearly all of the variation in rate of height increase $\left(r^{2}=0.97, p<0.01\right)$. Rainfall events had little discernable influence, but the plants were not exposed to prolonged soil drought during our study.

Vegetation type affected the rate of change in shoot weight (Fig. 7a) as well as the weight:height ratio (Fig. 7b). Shoots of western ragweed in mixed prairie gained weight more rapidly and weighed more per unit of height throughout the growing season than shoots in tallgrass prairie. Shoots of western ragweed in tallgrass prairie were less robust and had fewer branches and leaves on the lower portions of the shoots.

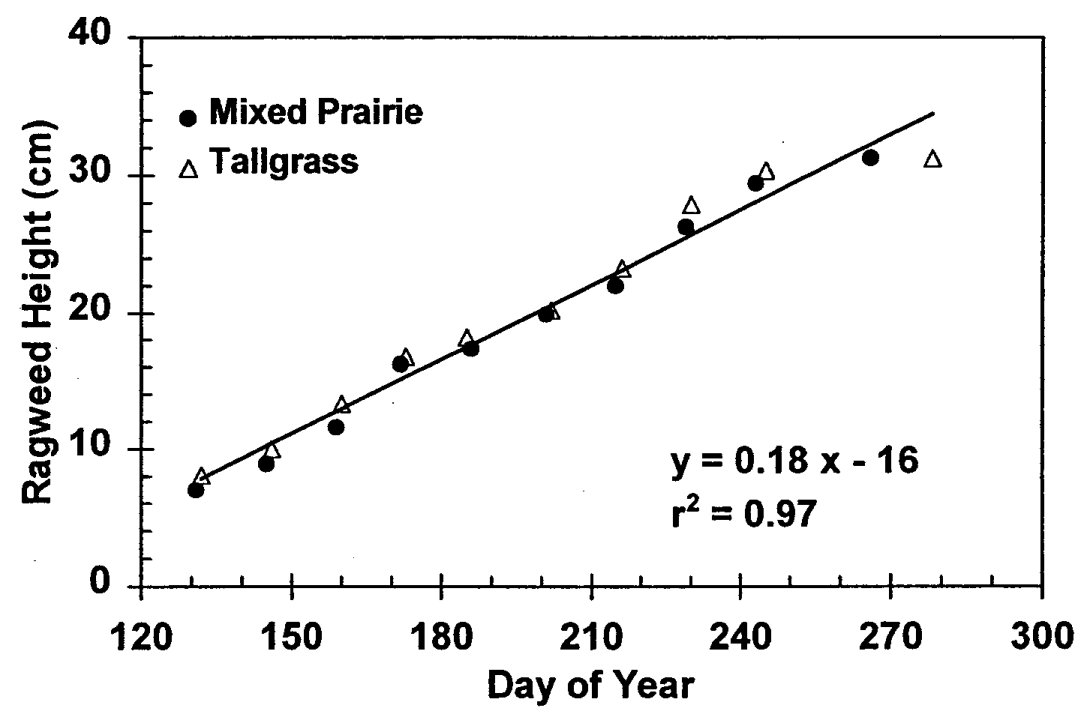

Fig. 6. Growth curve for western ragweed height. Models do not differ by vegetation type. 
Table 2. Height, weight, and weight:height ratio of shoots of western ragweed at the end of the grazing season as affected by grazing treatment averaged over vegetation type.

\begin{tabular}{lcc}
\hline \hline \multirow{2}{*}{ Management } & \multicolumn{2}{c}{ Treatment } \\
\cline { 2 - 3 } Height $(\mathrm{cm})$ & Grazed & Ungrazed. \\
Weight $(\mathrm{mg})$ & 1,290 & 30 \\
Weight:height ratio $\left(\mathrm{mg} \mathrm{cm}^{-1}\right)$ & $56 *$ & 29 \\
\hline *Indicates means within row are significantly different at \\
$\mathrm{P}<0.05$.
\end{tabular}

Grazing also affected the morphology of western ragweed shoots. Near the end of the grazing period, shoots of western ragweed in grazed plots were shorter than those in ungrazed plots (Table 2). Shoot weight was not influenced by grazing treatment, but western ragweed shoots in grazed plots weighed nearly twice as much per unit of height as those in ungrazed plots. These differences were consistent over vegetation types. Previous work in tallgrass prairie found that western ragweed shoots were taller and lighter in ungrazed plots compared to grazed plots (Fahnestock and Knapp 1993).

Competition for light is a limiting factor for growth of western ragweed in tallgrass prairie (Fahnestock and Knapp 1993). Competition for light is also an important factor in explaining the affect of vegetation type and grazing on the morphology of western ragweed shoots in this study. Plants with the least available light often have elongated internodes and less branching. Competition for light should be higher in tallgrass compared to mixed grass prairie and should also be higher in ungrazed versus grazed sites. Our results are consistent with these relationships, especially with respect to the weight:height ratio. Because of greater light availability in areas with lower standing crops of grasses, robust western ragweed plants are likely a result of, rather than the cause of, lower grass standing crop.

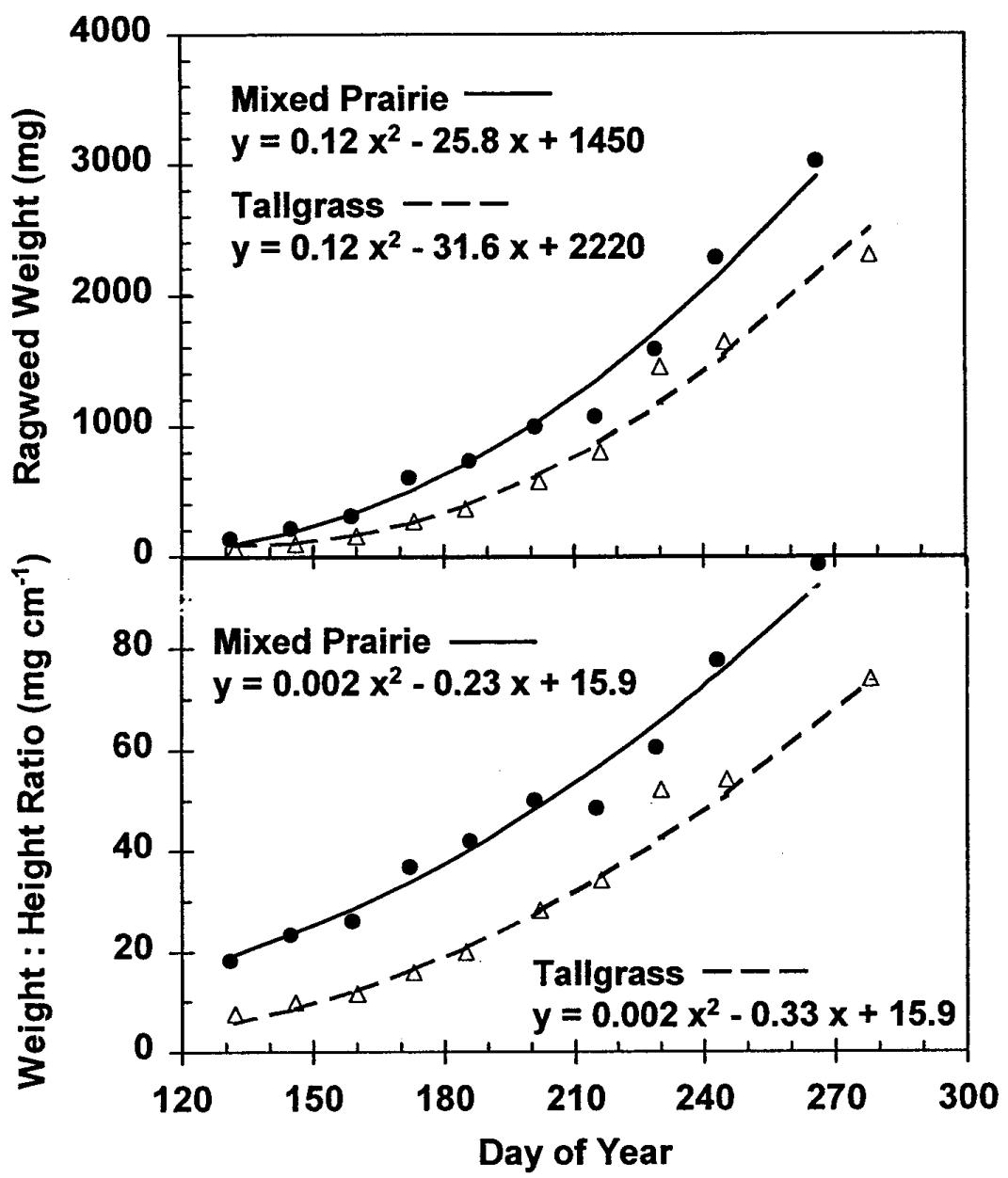

Fig. 7. Growth curves for western ragweed weight $\left(R^{2}=0.98\right.$ for system of equations) and weight:height ratio $\left(R^{2}=0.99\right.$ for system of equations). Models are significantly different between vegetation types.

\section{Management Implications}

Western ragweed has long been considered an aggressive competitor, but the results of our study question this conventional wisdom. The density of western ragweed decreases throughout the growing season and shoot morphology changes as grasses reduce the availability of light. Western ragweed's prominence in the forb component has likely led to the assumption that the majority of grass response to forb control is due to reduction of western ragweed.

Our study supports Launchbaugh (1967) who reported a positive relationship between grass standing crop and western ragweed standing crop below $1,230 \mathrm{~kg} \mathrm{ha}^{-1}$ in mixed prairie. An economic threshold for western ragweed control in mixed prairie has not been proposed, but our results suggest standing crops of at least $600 \mathrm{~kg} \mathrm{ha}^{-1}$ can be tolerated before control should be considered.

Western ragweed thrives where grass vigor has declined from grazing or drought in tallgrass prairie (Elder 1951, Bovey et al. 1966). Shoots of western ragweed are shorter in grazed environments but have more weight per unit of height. An abundance of western ragweed in tallgrass prairie likely indicates that grasses are over-utilized. However, in such cases, high levels of western ragweed are a result of, not a cause of, lower vigor of the grasses. If a reduction in western ragweed is desired, attention should first be directed toward improved grazing management. Future research should focus on determining competitive and economic thresholds for western ragweed in tallgrass and mixed prairies.

\section{Literature Cited}

Baumgartner, F. M., M. J. Morris, J. L. Steele, and J. E. Williams. 1952. Oklahoma bobwhite food relations. Trans. North Amer. Wildl. Conf. 17:338-358.

Bovey, R. W., M. K. McCarty, and F. S. Davis. 1966. Perennial ragweed on western Nebraska rangeland. J. Range Manage. 19:220-222.

Brummer, J. E., P. E. Reece, J. T. Nichols, and R. K. Engel. 1994. Western ragweed response to date and frequency of grazing sandhills vegetation. Soc for Range Manage. Abstracts for Ann. Meetings 47:63.

Dahl, B. E., J. C. Mosley, P. F. Cotter, and R. L. Dickerson, Jr. 1989. Winter forb control for increased grass yield on sandy rangeland. J. Range Manage. 42:400-403. 
Dwyer, D. D. 1958. Competition between forbs and grasses. J. Range Manage. 11:115-118.

Dormaar, J. F., B. W. Adams, and W. D. Willms. 1994. Effect of grazing and abandoned cultivation on a Stipa-Bouteloua community. J. Range Manage. 47:28-32.

Elder, W. C. 1951. Controlling perennial ragweed to make better pastures. Oklahoma Agr. Exp. Sta. Bull. No. 369. Stillwater, Okla.

Fahnestock, J. T. and A. K. Knapp. 1993. Water relations and growth of tallgrass prairie forbs in response to selective grass herbivory by bison. Int. J. Plant Sci. 154:432-440.

Heitschmidt, R. K., S. L. Dowhower, W. E. Pinchak, and S. K. Canon. 1989. Effects of stocking rate on quantity and quality of available forage in southern mixed grass prairie. $\mathrm{J}$. Range Manage. 42:468-473.

Launchbaugh, J. L. 1967. Vegetation relationships associated with intensity of summer grazing on a clay upland range site in the Kansas 20 to 24 inch precipitation zone. Kansas Agr. Exp. Sta. Bull. No. 154. Manhattan, Kan.
McCollum, F. T., R. L. Gillen, D. M. Engle, and G. W. Horn. 1990. Stocker cattle performance and vegetation response to intensive-early stocking of Cross Timbers rangeland. J. Range Manage. 43:99-103.

Moffatt, H. H. and A. J. Conradi. 1979. Soil survey Washita County, Oklahoma. USDA, Washington, D. C.

Myers, H. R. 1982. Climatological data of Stillwater, Oklahoma 1893-1980. Oklahoma Agr. Exp. Sta. Res. Rep. 821. Stillwater, Okla.

Neter, J. and W. Wasserman. 1974. Applied linear statistical models. Richard D. Irwin, Inc. , Chicago, Ill.

Powell, J., J. F. Stritzke, R. W. Hammond, and R. D. Morrison. 1982. Weather, soil and 2,4-D effects on tallgrass prairie in Oklahoma. J. Range Manage. 35:483-488.

Reece, P. E., J. E. Brummer, J. T. Nichols, and L. E. Moser. 1994. Competition between western ragweed and associated vegetation. Soc. for Range Management Abstracts for Ann. Meetings 47:82.
Rice, C. K. and J. F. Stritzke. 1989. Effects of 2,4-D and atrazine on degraded Oklahoma grasslands. J. Range Manage. 42:217-222.

SAS Institute. 1985. SAS/STAT Guide for personal computers, Version 6 edition. Cary, N.C.

Sims, P. L. and D. D. Dwyer. 1965. Pattern of retrogression of native vegetation in northcentral Oklahoma. J. Range Manage 18:20-25.

Smith, E. F. and C. E. Owensby. 1978. Intensive-early stocking and season-long stocking of Kansas Flint Hills range. J. Range Manage. 31:14-17.

Weaver, J. E. 1958. Classification of root systems of forbs of grassland and a consideration of their significance. Ecol. 39:393-401.

Whitham, W. C. 1971. Influence of grazing on the microclimate of mixed-grass prairie, $\mathrm{p}$. 207-218. In: K. M. Kreitlow and R. H. Hart (eds.), Plant morphogenesis as the basis for scientific management of range resources. USDA, Misc. Pub. 1271 Washington, D. C.

Wood, M. K and W. H. Blackburn. 1981. Grazing systems: Their influence on infiltration rates in the Rolling Plains of Texas. J. Range Manage. 34:331-335. 